\title{
Oospore Production of Phytophthora infestans in Potato and Tomato Leaves
}

\author{
Y. Cohen, S. Farkash, Z. Reshit, and A. Baider
}

Department of Life Sciences, Bar-Ilan University, Ramat Gan 52900, Israel. Accepted for publication 21 October 1996.

\begin{abstract}
Cohen, Y., Farkash, S., Reshit, Z., and Baider, A. 1997. Oospore production of Phytophthora infestans in potato and tomato leaves. Phytopathology $87: 191-196$.

Fungal, host, and environmental factors affecting sexual reproduction of Phytophthora infestans in planta were studied. Intact and detached leaves were coinoculated with sporangia of various combinations of $\mathrm{A}_{1}$ and $A_{2}$ mating-type isolates; leaves were incubated under various conditions, and oospore production was estimated microscopically within whole, clarified leaflets. Some $A_{1}+A_{2}$ isolate combinations were more reproductive than others, whereas some potato genotypes better supported oospore formation than others. Tomato usually supported more oospore formation than potato. To induce oospore formation, $A_{1}$ and $A_{2}$ sporangia were usually mixed at a 1:1 ratio. Ratios of $1: 19$ to $19: 1$, however, also allowed abundant production of oospores. Optimal temperatures for sexual sporulation ranged from 8 to $15^{\circ} \mathrm{C}$, but oospores also were produced

and oospores developed after 8 to 10 days. Light had little effect on oospore formation in both tomato and potato leaves provided that initial lesions were established under photoperiodic conditions. Although A1 and $\mathrm{A}_{2}$ sporangia usually were mixed before inoculation on leaves to obtain oospores, we found that discrete $\mathrm{A}_{1}$ and $\mathrm{A}_{2}$ lesions produced on opposite sides of the midvein of tomato leaves also induced oospore formation in the midvein and adjacent tissues. Oospores also formed when the two halves of the leaves were cut and separated at 3 days after sporangial coinoculation, which corresponded with the appearance of late blight lesions. The continuous supply of moisture to infected leaves was essential to oospore production. No oospores or oogonia formed in severely diseased plants kept at 50 to $80 \%$ relative humidity. Such plants did allow some oospore formation when kept continuously wet for 2 weeks in plastic boxes or tents. Detached leaves floated on water supported the highest sexual sporulation. Under optimal conditions of wetness and temperature, as many as 100 oospores per $\mathrm{mm}^{2}$ of tissue were observed.
\end{abstract} at $23^{\circ} \mathrm{C}$. Oogonia developed 5 to 6 days after sporangial coinoculation,
The migration of the $\mathrm{A}_{2}$ mating type of Phytophthora infestans from central Mexico to elsewhere in the Western Hemisphere in the late 1970 s $(4,5,10,13,15,18)$ created an opportunity for the fungus to reproduce sexually in areas where it was uncommon previously. P. infestans, a destructive pathogen of potato and tomato, produces oospores when $\mathrm{A}_{1}$ and $\mathrm{A}_{2}$ hyphae mate. Early observations of oospore production in planta were made in the highlands of central Mexico, where the two mating types occur in equal proportions $(6,17)$. Later studies made by Frinking et al. in the Netherlands (3) and Mosa et al. in Japan (14) revealed the production of oospores in stems, but rarely in leaves, of potato and tomato plants grown in greenhouses and inoculated with mixed $\mathrm{A}_{1}$ and $\mathrm{A}_{2}$ sporangia of $P$. infestans. In Israel, a small number of oospores also were found in tubers (9). In Europe, oospore formation in potato leaves was reported in Germany (8) and the Netherlands (2). Drenth (1) recently showed that oospores were produced in potato (cv. Bintje) leaves at temperatures ranging from 5 to $25^{\circ} \mathrm{C}$, with an optimum of $10^{\circ} \mathrm{C}$. More oospores were produced in leaves of a moderately resistant cultivar than in leaves of a highly susceptible cultivar. He also demonstrated that oospores of $P$. infestans can survive in soil during the winter and can later cause infection in potato leaves (1).

The objective of the current work was to study the influence of some biotic and environmental factors on oospore production in planta. Because some $A_{1}$ and $A_{2}$ pairs are more fertile than others, most of the work was conducted with the two most fertile pairs. Emphasis was placed on finding the marginal mixing ratios for coinoculated $A_{1}$ and $A_{2}$ sporangia that still allowed oospore formation. We show that even a small frequency of $\mathrm{A}_{2}$ sporangia, as it occurs in Europe (7), may induce oospore formation in planta.

Corresponding author: Y. Cohen; Fax: 972-3-5354133

Publication no. P-1997-0106-02R

(c) 1997 The American Phytopathological Society

\section{MATERIALS AND METHODS}

Fungal isolates. $\mathrm{A}_{1}$ and $\mathrm{A}_{2}$ isolates of $P$. infestans from Israel, Switzerland, and Japan were used. Most work was conducted with Israeli isolates Ein-Vered $\left(\mathrm{A}_{1}\right.$, metalaxyl sensitive $)$ and Sufa $\left(\mathrm{A}_{2}\right.$, metalaxyl resistant) and Japanese isolates (supplied by U. Gisi, Sandoz Agro Research, Basel, Switzerland) 314 ( $\mathrm{A}_{1}$, metalaxyl sensitive) and $317\left(\mathrm{~A}_{2}\right.$, metalaxyl resistant). Fungal isolates were propagated on potato tuber slices (cv. Alpha) at $14^{\circ} \mathrm{C}$ in the dark.

Host genotypes. Potato cvs. Alpha, Avondale, Mondial, Boron, Cara, and Clauster were used. Because fungal isolates carried seven virulence factors (numbers 1, 3, 4, 7, 8, 10, and 11), a set of potato differentials each carrying a single corresponding $\mathrm{R}$ gene also was tested. The set of 11 potato differentials was supplied by U. Gisi. Plants were grown in pots at 18 to $25^{\circ} \mathrm{C}$ in a greenhouse and used either intact or as detached leaves. Two cultivars of tomato, Baby and $\mathrm{M}-82$, also were used. Tomato plants were grown in a greenhouse at 22 to $28^{\circ} \mathrm{C}$.

Inoculation and incubation. Freshly produced sporangia were collected from potato tuber slices at 6 to 7 days after inoculation and used to inoculate whole potato plants or detached leaves of potato and tomato. Sporangia were suspended in glass-distilled water and kept on ice until use.

Inoculum concentration was adjusted to 2,000 sporangia per $\mathrm{ml}$ with the aid of a cytometer. Intact plants were inoculated by either spray or droplet (10- $\mu$ l each) application (10 droplets per leaflet). Inoculum was applied to the abaxial surfaces of detached leaves and incubated in the dark on moist filter paper in $20 \times 20-\mathrm{cm}$ plastic dishes at $14^{\circ} \mathrm{C}$ for $18 \mathrm{~h}$. When symptoms appeared, water was added to the plates in excess so all leaflets were uniformly floating on the water. Intact plants were kept first in a dew chamber at $15^{\circ} \mathrm{C}$ to ensure infection and then were transferred to Perspex (Critesa Corp., Barcelona, Spain) boxes $(40 \times 50 \times 60 \mathrm{~cm})$ in growth chambers $\left(15^{\circ} \mathrm{C}\right)$ or to a moist plastic tent in a greenhouse (18 to $\left.22^{\circ} \mathrm{C}\right)$. 

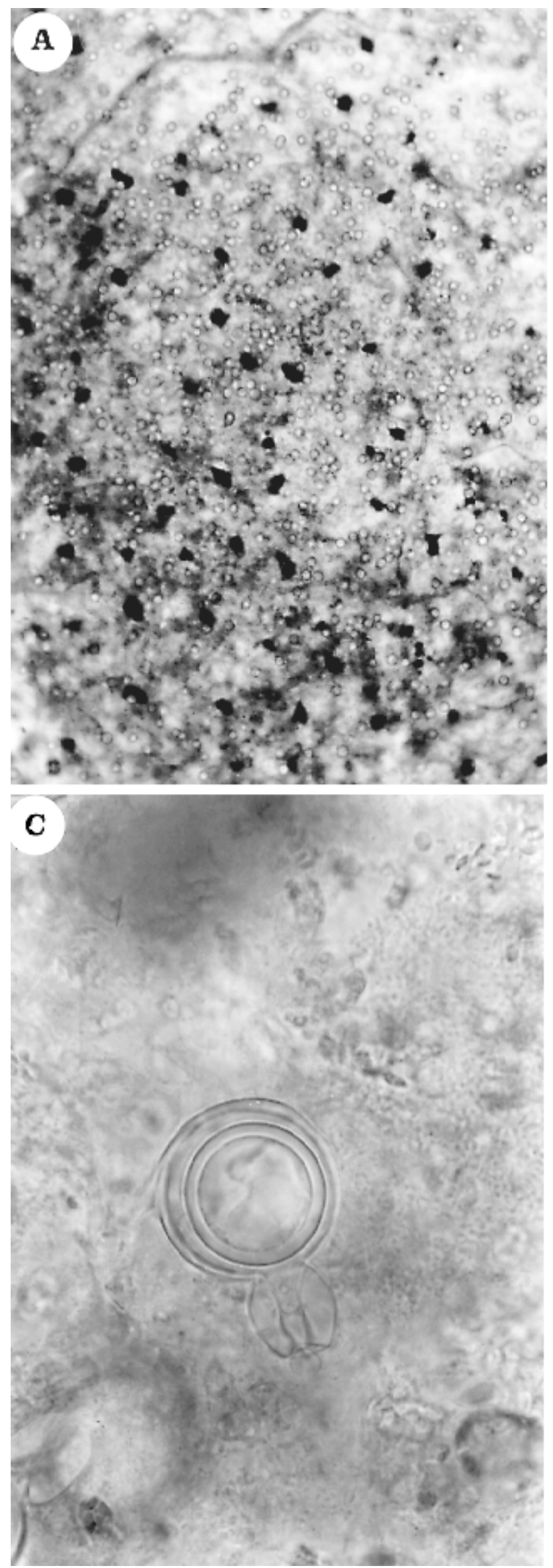

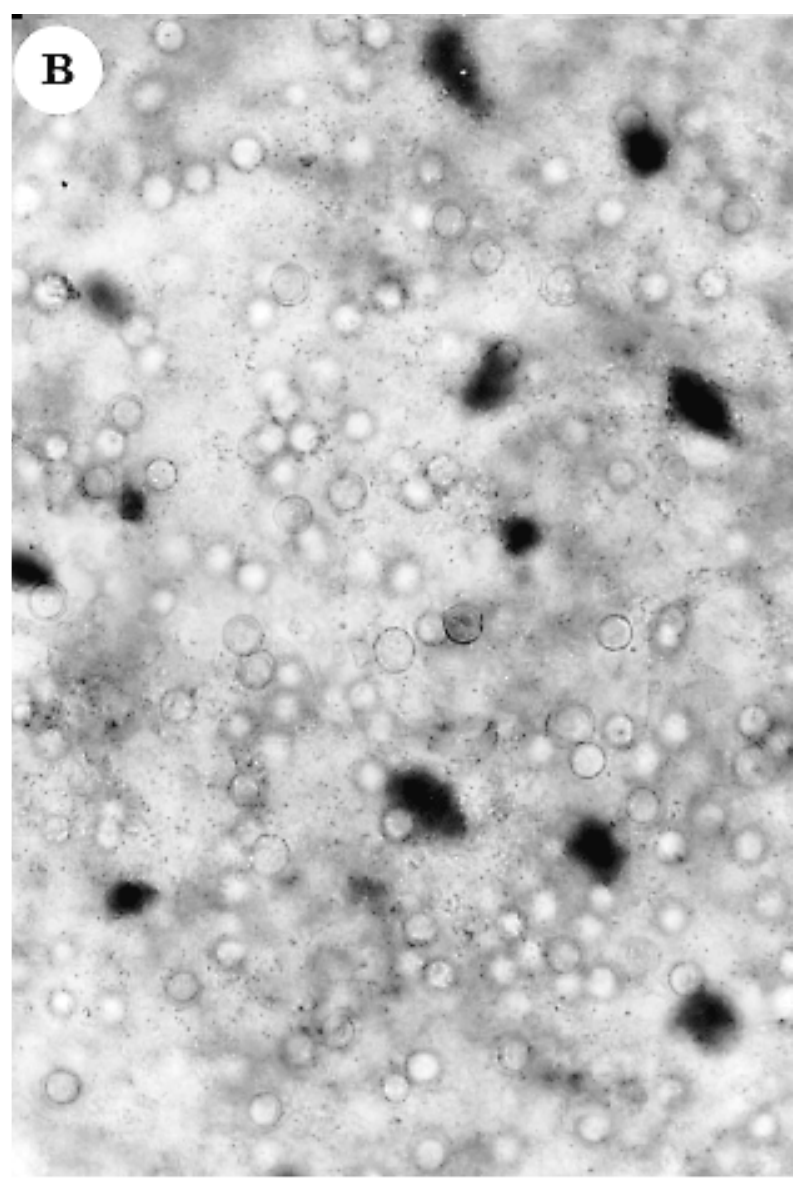

D

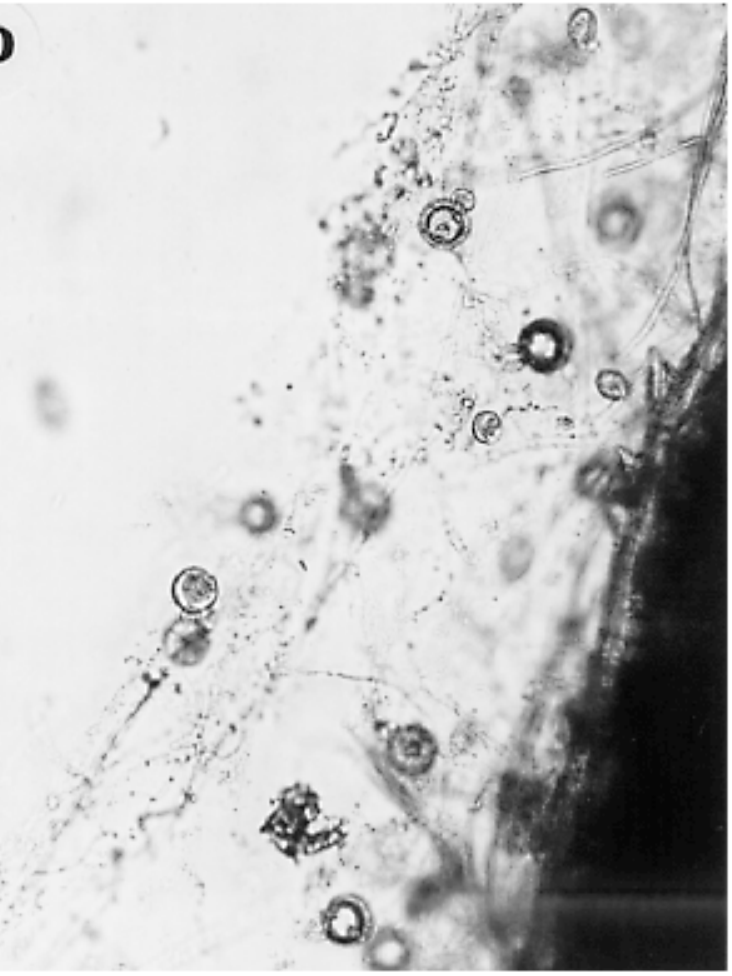

Fig. 1 A-D. Oospores of Phytophthora infestans in a tomato (cv. Baby) leaf coinoculated with $\mathrm{A}_{1}$ and $\mathrm{A}_{2}$ (314 and 317, respectively) mating-type isolates 2 weeks after inoculation at $15^{\circ} \mathbf{C}$. A and $\mathbf{B}$, Oospores at $\times 50$ and $\times 133$, respectively. $\mathbf{C}$, A single oospore at $\times 970$. The amphygynous antheridium is attached to the oospore, and the outer walls of the oospore are light in color. D, Oospore formation outside a tomato leaf at $\times 160$. Explained in text. 
Microscopic observations. To verify the occurrence of oogonia or oospores in tissue samples, leaflets first were gently washed with excessive water to remove sporangia from their surfaces and then clarified in boiling ethanol for $5 \mathrm{~min}$. After the ethanol treatment, they were again floated on water, and a glass slide was used to lift the tissue and mount it on the glass surface. Excessive water was absorbed, and 50\% glycerin solution was added before covering with a glass coverslip $(18 \times 50 \mathrm{~mm})$. The tissue was examined with a bright-field microscope at $\times 40$.

Data analysis. The number of oospores was counted at each of two $8-\mathrm{mm}^{2}$ sites per leaflet. Sites where oospore density seemed to be maximal were selected. Usually two to four leaflets were used per treatment, but in some experiments (e.g., effect of light and host genotype), six to eight leaflets were used. Most experiments were repeated at least once. Data from identical experiments resulting in similar oospore counts (e.g., effect of incubation conditions and mating-type ratio) were pooled before analysis. Analysis of variance was performed by the Duncan new multiple range test to establish significant differences at the $5 \%$ probability level.

\section{RESULTS}

Droplet coinoculation with $\mathrm{A}_{1}$ and $\mathrm{A}_{2}$ sporangia was very efficient in inducing oospore formation (Fig. 1A through C). Nonetheless, a large variation in oospore density occurred between lesions on the same leaflet and between lesions on different leaflets of the same treatment.

Oospore size and color in tomato and potato. Minor differences were observed between the oospore size of various pairs of $\mathrm{A}_{1}$ and $\mathrm{A}_{2}$ isolates in both potato and tomato. Oospore diameter was $\sim 30 \mu \mathrm{m}$. Detailed measurements conducted with leaves coinoculated with isolates $314\left(\mathrm{~A}_{1}\right)$ and $317\left(\mathrm{~A}_{2}\right)$ revealed that oospore diameters (25 each) were $29.9 \pm 0.5 \mu \mathrm{m}$ in tomato $\mathrm{cv}$. Baby; $30.2 \pm$ $0.6 \mu \mathrm{m}$ in tomato cv. M-82; $29.6 \pm 0.4 \mu \mathrm{m}$ in potato cv. Alpha; and $31.9 \pm 0.5 \mu \mathrm{m}$ in potato cv. Avondale. Oospores in cv. Avondale were significantly larger than in tomato or other potato cultivars $(P<0.05)$. At about 2 to 3 weeks after inoculation, oospores in potato were darker than in tomato, especially those in or adjacent to veins.

Effect of wetness on oospore formation. Intact potato or tomato plants coinoculated with mixed $\mathrm{A}_{1}$ and $\mathrm{A}_{2}$ sporangia did not support oospore formation when incubated at ambient relative humidity (RH) of 50 to $80 \%$ for up to 3 weeks at 12,15 , or $20^{\circ} \mathrm{C}$ in growth chambers. Such plants, even though fully blighted, showed no oospores. Placing infected plants in Perspex boxes or polyethylene tents equipped with humidifiers 1 day after inoculation allowed

TABLE 1. The effect of incubation conditions on the number of oospores of Phytophthora infestans produced in tomato leaves ${ }^{\mathrm{w}}$

\begin{tabular}{lcc}
\hline $\begin{array}{l}\text { Leaves intact } \\
\text { at ambient RH (days) }\end{array}$ & $\begin{array}{c}\text { Leaves detached and } \\
\text { floated on water (days) }\end{array}$ & Oospores $/ 8 \mathrm{~mm}^{2}$ \\
\hline 0 & 20 & $500 \pm 140^{\mathrm{x}}$ \\
1 & 19 & $520 \pm 80$ \\
2 & 18 & $475 \pm 125$ \\
3 & 17 & $500 \pm 100$ \\
$5^{\mathrm{y}}$ & 15 & $70 \pm 24$ \\
$6^{\mathrm{y}}$ & 14 & $50 \pm 40$ \\
$7^{\mathrm{z}}$ & 13 & 0 \\
$8^{\mathrm{z}}$ & 12 & 0 \\
\hline
\end{tabular}

w Tomato plants with 10 leaves were inoculated with sporangia of $P$. infestans on leaf numbers 4 and 5 with $1010-\mu$ d droplets per leaflet, containing 20 sporangia (10 of isolate $314\left[\mathrm{~A}_{1}\right]$ and 10 of isolate $317\left[\mathrm{~A}_{2}\right]$ ), placed in a dew chamber at $15^{\circ} \mathrm{C}$ for $20 \mathrm{~h}$, and incubated at $12 \pm 1^{\circ} \mathrm{C}$ with a 14-h photoperiod $\left(100 \mu \mathrm{E} \mathrm{m}^{-2} \mathrm{~s}^{-1}\right)$ and 50 to $60 \%$ relative humidity $(\mathrm{RH})$. Inoculated leaflets were detached at various time intervals after inoculation and floated on water in closed dishes in the same chamber.

${ }^{x}$ Number plus/minus standard deviation.

y Late blight lesion appearance.

${ }^{\mathrm{z}}$ Intact inoculated leaves totally blighted. some oospore production, especially in defoliated leaves lying on the soil surface of the pots. Also, incubation of infected plants outdoors during the rainy season (December to January) allowed only a few oospores to be produced. It became apparent that keeping the infected leaves in continuous contact with water is crucial for the infected leaf tissue to support oospore production.

For oospore production, blighted tomato leaves coinoculated with $A_{1}$ and $A_{2}$ sporangia should not remain attached to the plant for more than 6 days after inoculation (Table 1). When leaves were detached at 0 to 6 days after inoculation and placed on a film of water in closed dishes, oospores were produced. Leaves detached and floated on water before lesions formed produced significantly more oospores than those detached and floated after lesion appearance (Table 1). Fully necrotized leaves failed to produce oospores even when floated on water. Those parts of a leaf or leaflet that curled and had no direct contact with water produced fewer oospores compared to tissue that touched the water.

Effect of $\mathbf{A}_{1} / \mathbf{A}_{2}$ ratio. When $\mathrm{A}_{1}$ sporangia of either isolate 314 or Ein-Vered were inoculated alone on detached tomato or potato leaves and incubated at 12 or $15^{\circ} \mathrm{C}$ for 2 or 3 weeks, no oospores formed in the blighted tissues. Similarly, $\mathrm{A}_{2}$ sporangia of isolates 317 or Sufa alone did not produce oospores (Table 2). However, when $A_{1}$ and $A_{2}$ sporangia were mixed before inoculation, numerous oospores were produced inside infected tissue. The ratio between $A_{1} / A_{2}$ sporangia in the sporangial inoculum had a minor effect on the number of oospores produced. Because each inoculum droplet contained a mean of 20 sporangia $( \pm 2)$, the extreme

TABLE 2. Effect of the $A_{1} / A_{2}$ mating type ratio in sporangial inoculum on the number of oospores of Phytophthora infestans produced in tomato and potato leaves ${ }^{\mathrm{w}}$

\begin{tabular}{lcc}
\hline & \multicolumn{2}{c}{ Host $^{\mathrm{x}}$} \\
\cline { 2 - 3 }$\% \mathrm{~A}_{2}$ & Tomato $\left(\mathrm{cv}\right.$. Baby) $^{\mathrm{y}}$ & Potato $^{\mathrm{z}}$ \\
\hline 0 & 0 & 0 \\
5 & $272 \pm 170$ & $175 \pm 146$ \\
10 & $321 \pm 148$ & $221 \pm 139$ \\
25 & $406 \pm 114$ & $142 \pm 60$ \\
50 & $407 \pm 203$ & $277 \pm 255$ \\
75 & $285 \pm 85$ & $267 \pm 140$ \\
90 & $240 \pm 40$ & $290 \pm 168$ \\
95 & $207 \pm 7$ & 0 \\
100 & 0 & $232 \pm 135$ \\
\hline
\end{tabular}

${ }^{w}$ Detached leaves were floated on water in petri dishes and inoculated with $1010-\mu l$ droplets per leaflet, each containing 20 sporangia. $\mathrm{A}_{1}$ and $\mathrm{A}_{2}$ sporangia were mixed at various ratios $(1: 19$ to $19: 1)$ before inoculation.

${ }^{x}$ Values represent the mean number of oospores per $8 \mathrm{~mm}^{2}$ of leaf tissue plus/minus standard deviation.

y $\mathrm{A}_{1}$ from isolate $314 ; \mathrm{A}_{2}$ from isolate 317 . Compiled mean values from three independent experiments conducted with four leaflets per ratio at $12^{\circ} \mathrm{C}$ for 15 days.

${ }^{\mathrm{z}} \mathrm{A}_{1}$ from isolate Ein-Vered; $\mathrm{A}_{2}$ from isolate Sufa. Compiled mean values were taken from potato differentials $\mathrm{R}_{0}, \mathrm{R}_{1}, \mathrm{R}_{3}, \mathrm{R}_{4}, \mathrm{R}_{7}$, and $\mathrm{R}_{8}$; three leaflets per genotype per ratio, at $15^{\circ} \mathrm{C}$ for 21 days.

TABLE 3. Effect of host and duration of incubation period on the number of oospores produced by Phytophthora infestans at $11^{\circ} \mathrm{C}$

\begin{tabular}{llcccr}
\hline & & \multicolumn{4}{c}{ Incubation period (days) $^{\mathrm{z}}$} \\
\cline { 4 - 6 } Host & Cultivar & 10 & 13 & 17 & \multicolumn{1}{c}{23} \\
\hline Tomato & Baby & $170 \pm 113$ & $283 \pm 107$ & $217 \pm 37$ & $425 \pm 83$ \\
Potato & Avondale & $44 \pm 36$ & $63 \pm 22$ & $113 \pm 54$ & $100 \pm 10$ \\
Potato & Alpha & $1 \pm 2$ & $38 \pm 13$ & $200 \pm 82$ & $250 \pm 50$ \\
Potato & Boron & $11 \pm 5$ & $57 \pm 33$ & $125 \pm 43$ & $88 \pm 22$ \\
Potato & Mondial & $10 \pm 6$ & $125 \pm 43$ & $150 \pm 50$ & $400 \pm 71$ \\
\hline
\end{tabular}

${ }^{y}$ Detached leaves floating on water in dishes were inoculated with $1010-\mu \mathrm{l}$ droplets per leaflet of sporangial suspension, containing 10 sporangia of isolate $314\left(\mathrm{~A}_{1}\right)$ and 10 sporangia of isolate $317\left(\mathrm{~A}_{2}\right)$ per droplet. Leaves were placed for $15 \mathrm{~h}$ at $14^{\circ} \mathrm{C}$ in the dark and at $11^{\circ} \mathrm{C}$ in a chamber with a $14-\mathrm{h}$ photoperiod.

$\mathrm{z}$ Values represent the mean number of oospores per $8 \mathrm{~mm} 2$ of leaf tissue averaged over three leaflets plus/minus standard deviation. 
proportions statistically possible were 1 sporangium of $A_{1}$ and 19 sporangia of $A_{2}$ and vice versa, i.e., ratios of 5:95 to 95:5; even at these extreme proportions of mating types, abundant oospores were produced in leaves of both tomato and potato genotypes (Table 2).

Effect of fungal isolate. Field isolates of $P$. infestans varied in their reproductive capacity when mixed 1:1 $\left(\mathrm{A}_{1} / \mathrm{A}_{2}\right)$ and inoculated on susceptible tomato or potato leaves. Some $A_{1}$ and $A_{2}$ pairs produced abundant oospores, whereas others produced only a few on the same host (tomato or potato). Production of oospores in leaves of a susceptible host did not depend on the geographic origin of the isolate (Israel, Japan, and Switzerland), number of virulence factors carried by the isolate, or sensitivity to metalaxyl.

Effect of host. Production of oospores by isolates $314\left(\mathrm{~A}_{1}\right)$ and 317 (A2) was studied first at $11^{\circ} \mathrm{C}$ with tomato $\mathrm{cv}$. Baby and potato cvs. Avondale, Alpha, Boron, and Mondial. Ten days after inoculation with mixed (1:1) sporangial inoculum, oospores were seen in all leaves examined, but their number in tomato was much higher than in potato. Oospore counts increased with time, reaching the highest level at 17 or 23 days. Tomato cv. Baby and potato cv. Mondial were highest, whereas potato cvs. Boron and Avondale were lowest in oospore production (Table 3 ).

Results were different for other pairs of $A_{1}$ and $A_{2}$ isolates. For example, isolates Ein-Vered $\left(\mathrm{A}_{1}\right)$ and Sufa $\left(\mathrm{A}_{2}\right)$ produced 260, 38, and 14 oospores per $8 \mathrm{~mm}^{2}$ of leaf tissue in potato cvs. Boron and Alpha and tomato cv. Baby, respectively, after 28 days of incubation at $15^{\circ} \mathrm{C}$. Further experiments revealed (data not shown) that various pairs of $A_{1}$ and $A_{2}$ isolates differ in their sexual reproduction in susceptible tomato and potato cultivars.

Late blight resistance genes carried by potato differentials had a minor effect on oospore production (Table 4) when both isolates carried the corresponding virulence factors for successful colonization of leaves.

Effect of temperature. Influence of temperature was studied in two tomato and four potato cultivars coinoculated with isolates $314\left(\mathrm{~A}_{1}\right)$ and $317\left(\mathrm{~A}_{2}\right)$ at a ratio of 1:1. Leaf samples were taken for microscopic examination 20 days after inoculation. Oospores were formed at 8 to $23^{\circ} \mathrm{C}$. Their abundance depended mainly on the temperature but also, slightly, on the host and cultivar (Table 5). In tomato, a significantly higher number of oospores was produced at $8^{\circ} \mathrm{C}$ (cv. Baby) and 8 and $11^{\circ} \mathrm{C}(\mathrm{cv}$. M-82) compared to higher temperatures. In potato cv. Avondale, a significantly higher number of oospores was produced at $8^{\circ} \mathrm{C}$ compared to at 11 to $23^{\circ} \mathrm{C}$. In cv. Alpha, oospore counts did not differ significantly among temperatures. In cv. Boron at 8 to $15^{\circ} \mathrm{C}$ and in $\mathrm{cv}$. Clauster at 8 to $18^{\circ} \mathrm{C}$, significantly more oospores were produced compared to at 18 to 23 and $23^{\circ} \mathrm{C}$, respectively. Pooling the data for all hosts revealed that lower $\left(8\right.$ to $\left.11^{\circ} \mathrm{C}\right)$ temperatures were significantly more conducive to oospore formation compared to higher (18 to $23^{\circ} \mathrm{C}$ ) temperatures (Table 5).

Various hosts behaved differently at each temperature. Thus, tomato $\mathrm{cv}$. Baby produced significantly more oospores than tomato cv. M- 82 at 8 and $15^{\circ} \mathrm{C}$ but not at other temperatures and more than the potato cultivars, except Avondale. As temperature increased, differences between hosts tended to decrease: at 18 and $23^{\circ} \mathrm{C}$, no or minor statistical differences in oospore counts were seen. Pooling the data for all temperatures revealed no significant differences between hosts in their support of oospore production (Table 5).

Effect of light intensity. Detached leaves of tomato (cv. Baby) and potato (cvs. Avondale, Alpha, and Cara or Alpha, $\mathrm{R}_{1}$, and $\mathrm{R}_{4}$ ) were placed on water in dishes and inoculated with a mixture (1:1) of sporangia of isolates $314\left(\mathrm{~A}_{1}\right)$ and $317\left(\mathrm{~A}_{2}\right)$. Plates were incubated at $14^{\circ} \mathrm{C}$ for $20 \mathrm{~h}$ in the dark to ensure infection and transferred to a growth chamber (14-h photoperiod) illuminated with VHO fluorescent lamps at $160 \mu \mathrm{E} \mathrm{m}^{-2} \mathrm{~s}^{-1}$ at $15^{\circ} \mathrm{C}$. Three days after inoculation, when lesions emerged, plates were covered with black plastic nets (50 mesh) or aluminum foil to achieve a light intensity of $160,80,40$, or $0 \mu \mathrm{E} \mathrm{m}^{-2} \mathrm{~s}^{-1}$ at the leaf level. At 9,13 , and 20 days after inoculation, leaf samples were examined for the presence of oospores. Results presented in Table 6 show that oospores were produced under all light regimes, including darkness.

At 9 days after inoculation, tomato $\mathrm{cv}$. Baby and potato $\mathrm{cv}$. Alpha showed significantly more oospore production at 80 and 160 as compared to 0 and $40 \mu \mathrm{E} \mathrm{m}^{-2} \mathrm{~s}^{-1}$. At this time, potato cvs. $\mathrm{R}_{1}$ and $\mathrm{R}_{4}$ produced significantly more oospores in the light than in the dark (Table 6). At 13 days after inoculation, tomato cv. Baby and potato cv. Alpha showed no significant differences in oospore density among the light regimes. In cv. Avondale, full light was superior to reduced light levels or darkness, whereas in cv. Cara, half light was significantly better than other treatments. At 20 days, tomato cv. Baby and potato cv. Avondale were unaffected by light. In contrast, potato cvs. Alpha and Cara

TABLE 4. Number of oospores produced by isolates $314\left(\mathrm{~A}_{1}\right)$ and $317\left(\mathrm{~A}_{2}\right)$ of Phytophthora infestans in leaves of potato differentials carrying major genes for resistance to late blight at $15^{\circ} \mathrm{C}$

\begin{tabular}{lccccccccccccc}
\hline & \multicolumn{10}{c}{ Host differential $^{\mathrm{z}}$} \\
\cline { 2 - 11 } Incubation period & 0 & 1 & 2 & 3 & 4 & 5 & 6 & 7 & 8 & 9 & 10 \\
\hline 9 days & $360 \mathrm{a}$ & $200 \mathrm{ab}$ & $\mathrm{R}$ & $135 \mathrm{ab}$ & $55 \mathrm{~b}$ & $\mathrm{R}$ & $\mathrm{R}$ & $90 \mathrm{ab}$ & $100 \mathrm{ab}$ & $\mathrm{R}$ & $0 \mathrm{c}$ & $200 \mathrm{ab}$ \\
14 days & $375 \mathrm{a}$ & $250 \mathrm{ab}$ & $\mathrm{R}$ & $400 \mathrm{a}$ & $350 \mathrm{a}$ & $\mathrm{R}$ & $\mathrm{R}$ & $150 \mathrm{ab}$ & $250 \mathrm{ab}$ & $\mathrm{R}$ & $100 \mathrm{ab}$ & $360 \mathrm{a}$ \\
\hline
\end{tabular}

${ }^{\mathrm{z}} \mathrm{R}=\mathrm{a}$ resistant genotype, produces a hypersensitive response. Different letters following values within each row indicate significant differences between hosts at the 5\% probability level (Duncan multiple range test).

TABLE 5. Effect of temperature on the number of oospores produced by isolates $314\left(\mathrm{~A}_{1}\right)$ and $317\left(\mathrm{~A}_{2}\right)$ of Phytophthora infestans in leaves of tomato and potato cultivars ${ }^{\mathrm{z}}$

\begin{tabular}{|c|c|c|c|c|c|c|c|}
\hline \multirow[b]{2}{*}{ Host } & \multirow[b]{2}{*}{ Cultivar } & \multicolumn{6}{|c|}{ Temperature (C) } \\
\hline & & 8 & 11 & 15 & 18 & 23 & Mean cultivar \\
\hline Tomato & Baby & 575 a A & $325 \mathrm{~b} \mathrm{~A}$ & $350 \mathrm{~b} \mathrm{~A}$ & $25 \mathrm{c} \mathrm{AB}$ & $5 \mathrm{cB}$ & $256 \mathrm{~A}$ \\
\hline Tomato & M-82 & 300 a BC & 325 a A & $125 \mathrm{~b} \mathrm{~B}$ & $10 \mathrm{c} \mathrm{B}$ & $0 \mathrm{c} \mathrm{B}$ & $152 \mathrm{~A}$ \\
\hline Potato & Avondale & 500 a $\mathrm{AB}$ & $238 \mathrm{~b} \mathrm{AB}$ & $88 \mathrm{c} \mathrm{B}$ & $40 \mathrm{c} \mathrm{AB}$ & $43 \mathrm{c} \mathrm{A}$ & $181 \mathrm{~A}$ \\
\hline Potato & Alpha & 118 a C & 175 a $\mathrm{ABC}$ & 43 a B & 31 a $\mathrm{AB}$ & 55 a $\mathrm{A}$ & $84 \mathrm{~A}$ \\
\hline Potato & Boron & 138 a C & 113 a BC & $55 \mathrm{ab} B$ & $4 \mathrm{~b} \mathrm{~B}$ & $3 \mathrm{~b} \mathrm{~B}$ & $62 \mathrm{~A}$ \\
\hline Potato & Clauster & 213 a C & $43 a b C$ & $55 \mathrm{ab} B$ & $88 \mathrm{ab} \mathrm{A}$ & $3 \mathrm{~b} \mathrm{~B}$ & $80 \mathrm{~A}$ \\
\hline Mean temperature & & $307 \mathrm{a}$ & $203 \mathrm{ab}$ & $119 b c$ & $33 \mathrm{c}$ & $18 \mathrm{c}$ & \\
\hline
\end{tabular}

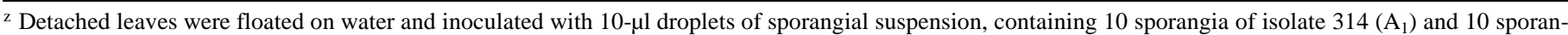
gia of isolate $317\left(\mathrm{~A}_{2}\right)$ per droplet $\left(10\right.$ droplets per leaflet). Leaves were first placed in the dark for $20 \mathrm{~h}$ at $14^{\circ} \mathrm{C}$ and then at various temperatures $(14$-h photoperiod, $100 \mu \mathrm{E} \mathrm{m}^{-2} \mathrm{~s}^{-1}$ ) for 20 days. Values represent the mean number of oospores per $8 \mathrm{~mm}^{2}$ of leaf tissue averaged from four leaves. Different small letters following values within each row and capital letters following values within each column indicate significant differences at the 5\% probability level (Duncan multiple range test) between temperatures and hosts, respectively. 
yielded significantly more oospores at 80 and 160 than at 0 and $40 \mu \mathrm{E} \mathrm{m}^{-2} \mathrm{~s}^{-1}$.

Oospore formation in discrete $A_{1}$ and $A_{2}$ lesions. Detached tomato leaflets (cv. Baby) were inoculated with five droplets of $A_{1}$ sporangia (isolate 314 ) on one side of the midvein and with five droplets of $\mathrm{A}_{2}$ sporangia (isolate 317 ) on the other side of the midvein or with $A_{1}$ on the proximal half of the leaflet and $A_{2}$ on its distal half (or vice versa). Inoculated leaflets were placed on water in dishes at $15^{\circ} \mathrm{C}\left(14 \mathrm{~h}\right.$ of light per day, $\left.80 \mu \mathrm{E} \mathrm{m} \mathrm{m}^{-2} \mathrm{~s}^{-1}\right)$ and examined after 2 weeks for the presence of oospores. In other experiments, the two halves of the leaflets were separated by cutting with a scalpel 3 or 4 days after inoculation, when lesions had just appeared. When leaflets remained uncut, abundant oospores formed inside the tissue in the interface zone between the lesions. In leaflets inoculated on the two sides of the midvein, oospores accumulated mainly in the midvein and along its adjacent tissues, from both sides, to a distance of 2 to $3 \mathrm{~mm}$. In leaflets inoculated on the proximal and distal ends, a middle zone $\sim 8$ to $12 \mathrm{~mm}$ wide contained numerous oospores. Cutting the two halves of a leaflet along the midvein revealed oospore formation in the tissue adjacent to the cuts and, surprisingly, also on hyphae growing from the tissue into the surrounding water (Fig. 1D).

\section{DISCUSSION}

Circumstantial evidence $(1,2,4,5,10,13,18)$ indicates the "old" $\mathrm{A}_{1}$ $P$. infestans population has been displaced by a "new" population consisting of both $A_{1}$ and $A_{2}$ isolates. DNA fingerprinting with the probe RG-57 showed dramatic genetic diversity in the newly established population, justifying the assumption of sexual reproduction of the fungus (1). Indeed, oospores were reported in nature in Germany (8,15), Holland (1-3), Japan (14), and Israel (9), but direct proof of their germination and infection is still missing.

The role of oospores of $P$. infestans in the epidemiology of late blight in potato and tomato is still unclear. The conditions under which oospores can be produced in planta are only partially known. The ability of oospores to survive in nature is uncertain, and most importantly, whether oospores can germinate and infect potato and tomato under field conditions and specific circumstances has yet to be shown. It is difficult to verify that oospores present in infected leaves are responsible for a resultant infection (1), because vegetative hyphae of the $A_{1}$ and $A_{2}$ isolates used are still present, and they also may cause infection (Y. Cohen and S. Farkash, unpublished data; [16]).

The current study, which addresses the first point of oospore production in planta, demonstrates that a constant supply of free moisture to blighted lesions is important for sexual reproduction of $P$. infestans in host tissue. Wetness has to last for a week or longer to ensure oosporogenesis. Infected leaves incubated at 50 to $80 \%$ RH produce no oospores, confirming earlier results (1). Parts of a leaf that have no direct contact with water produce no oospores. The practical implication is that prolonged rainy periods in nature may favor oospore production. In the absence of continuous moisture on leaves, infected defoliated leaves lying on wet soil in a field may produce oospores only if they were detached early enough after infection, which is unlikely. Another question is how oospore production will be affected by interrupted wetting periods. Under Israeli conditions, very few oospores were produced in nature during the rainy season (Y. Cohen, unpublished data).

Temperatures ranging from 8 to $23^{\circ} \mathrm{C}$ allow oospore formation, with maximum production at $8^{\circ} \mathrm{C}$. This means that favorable temperature regimes for late blight epidemic development $\left(15\right.$ to $\left.20^{\circ} \mathrm{C}\right)$ do not necessarily coincide with those most favorable for sexual reproduction. Drenth (1) explained that $10^{\circ} \mathrm{C}$ is more favorable for oospore formation in potato than 15 or $20^{\circ} \mathrm{C}$ because it delays lesion development and allows more time for oospores to be produced. Light had an inconsistent effect on oospore yield, varying with time of incubation and host. In all cases, oospores were formed under both light and dark conditions.

The ratio of coinoculated $A_{1}$ and $A_{2}$ mating types was not an important factor in production of oospores. Even a ratio of $1 \mathrm{~A}_{1}: 19$ $A_{2}$ or $19 A_{1}: 1 A_{2}$ resulted in oospore production. No statistical differences in oospore formation were observed among sporangial mixtures containing 5 to $95 \% \mathrm{~A}_{2}$ sporangia. The practical implication of this finding is that a low proportion of $\mathrm{A}_{2}$ sporangia in the field (in Europe 20\% or less [7]) may suffice for sexual reproduction of the pathogen. The dogma that a ratio of 1:1 mating types is required for oospore formation probably stems from the fact that in central Mexico, where oospores are common, $\mathrm{A}_{1}$ and $\mathrm{A}_{2}$ exist at a $1: 1$ ratio $(6,15)$. This composition probably reflects the mode of inheritance of the mating-type trait rather than the ratio required for oospore production.

We also showed that $A_{1}$ and $A_{2}$ sporangia do not need to be mixed before being coinoculated. Discrete lesions of $A_{1}$ or $A_{2}$ produced on opposite sides of a tomato leaflet were capable of producing oospores in the midvein and adjacent tissues. These discrete lesions also may be dissected when young and subsequently form oospores. It is possible that a mutual hormonal induction, similar to that reported in vitro $(11,12)$ for Phytophthora takes place in planta before dissection and is sufficient for oospore formation. Such putative hormonal induction did not operate between $A_{1}$ and $A_{2}$ lesions residing on opposite leaflets of a single tomato compound leaf, and therefore, no oospores were seen in such lesions (data not shown).

The host genotype had no significant effect on oospore formation. A potato lacking $\mathrm{R}$ genes for resistance to late blight allowed a number of oospores to be formed that was similar to susceptible genotypes carrying corresponding $\mathrm{R}$ genes. Tomato generally supported more oospore production than potato. The effect of the host varied with time and temperature in an inconsistent manner.

We conclude that $P$. infestans can readily produce oospores in detached tomato and potato leaves provided constant free moisture is applied. Oospore formation is favored by relatively low temperatures but can occur at $23^{\circ} \mathrm{C}$. A small proportion of an opposite mating type is necessary for oospore formation. Current studies concentrate on oospore germination and their infectivity on tomato and potato.

TABLE 6. Effect of light intensity on oospore formation of Phytophthora infestans in tomato and potato leaves at $15^{\circ} \mathrm{C}^{\mathrm{z}}$

\begin{tabular}{llrrrrr} 
& & \multirow{2}{*}{$\begin{array}{c}\text { Days after } \\
\text { inoculation }\end{array}$} & \multicolumn{4}{c}{ Light intensity $\left(100 \mu \mathrm{E} \mathrm{m}^{-2} \mathrm{~s}^{-1}\right)$} \\
\cline { 5 - 7 } Host & Cultivar & 0 & 40 & 80 & 160 \\
\hline Tomato & Baby & 9 & $38 \mathrm{~b}$ & $59 \mathrm{~b}$ & $137 \mathrm{a}$ & $159 \mathrm{a}$ \\
Potato & Alpha & & $25 \mathrm{~b}$ & $13 \mathrm{~b}$ & $128 \mathrm{a}$ & $98 \mathrm{a}$ \\
Potato & $\mathrm{R}_{1}$ & & $69 \mathrm{~b}$ & $396 \mathrm{a}$ & $397 \mathrm{a}$ & $391 \mathrm{a}$ \\
Potato & $\mathrm{R}_{4}$ & & $77 \mathrm{~b}$ & $248 \mathrm{a}$ & $253 \mathrm{a}$ & $312 \mathrm{a}$ \\
Tomato & Baby & 13 & $138 \mathrm{a}$ & $63 \mathrm{a}$ & $88 \mathrm{a}$ & $188 \mathrm{a}$ \\
Potato & Avondale & & $150 \mathrm{~b}$ & $100 \mathrm{~b}$ & $100 \mathrm{~b}$ & $365 \mathrm{a}$ \\
Potato & Alpha & & $150 \mathrm{a}$ & $113 \mathrm{a}$ & $188 \mathrm{a}$ & $250 \mathrm{a}$ \\
Potato & Cara & & $125 \mathrm{~b}$ & $75 \mathrm{~b}$ & $300 \mathrm{a}$ & $175 \mathrm{~b}$ \\
Tomato & Baby & 20 & $375 \mathrm{a}$ & $120 \mathrm{a}$ & $200 \mathrm{a}$ & $310 \mathrm{a}$ \\
Potato & Avondale & & $450 \mathrm{a}$ & $325 \mathrm{a}$ & $325 \mathrm{a}$ & $310 \mathrm{a}$ \\
Potato & Alpha & & $150 \mathrm{~b}$ & $120 \mathrm{~b}$ & $700 \mathrm{a}$ & $725 \mathrm{a}$ \\
Potato & Cara & & $315 \mathrm{~b}$ & $145 \mathrm{~b}$ & $500 \mathrm{a}$ & $550 \mathrm{a}$ \\
\hline
\end{tabular}

${ }^{\mathrm{z}}$ Detached leaves were floated on water and inoculated with $10-\mu$ droplets of sporangial suspension, containing 10 sporangia of isolate $314\left(\mathrm{~A}_{1}\right)$ and 10 sporangia of isolate $317\left(\mathrm{~A}_{2}\right)$ per droplet (10 droplets per leaflet). Leaves were placed in the dark for $20 \mathrm{~h}$ at $14^{\circ} \mathrm{C}$ and for 3 days at $15^{\circ} \mathrm{C}$ until lesions appeared and, afterward, were transferred to the indicated light regimes (14-h photoperiod). Values represent the mean number of oospores per $8 \mathrm{~mm}^{2}$ of leaf tissue averaged from four leaves. Different small letters following values within each row indicate significant differences at the $5 \%$ probability level (Duncan multiple range test) between light regimes. 


\section{ACKNOWLEDGMENTS}

Research was supported by Sandoz Agro Research, Basel, Switzerland.

\section{LITERATURE CITED}

1. Drenth, A. 1994. Molecular genetic evidence for a new sexually reproducing population of Phytophthora infestans in Europe. Ph.D. thesis. University of Wageningen, Wageningen, Netherlands.

2. Drenth, A., Turkensteen, L. J., and Govers, F. 1993. The occurrence of the $\mathrm{A}_{2}$ mating type of Phytophthora infestans in the Netherlands: Significance and consequences. Neth. J. Plant Pathol. 99:57-67.

3. Frinking, H. D., Davidse, L. C., and Limburg, H. 1987. Oospore formation by Phytophthora infestans in host tissue after inoculation with isolates of opposite mating type found in the Netherlands. Neth. J. Plant Pathol. 93:147-149.

4. Fry, W. E., Goodwin, S. B., Dyer, A. T., Matuszak, J. M., Drenth, A., Tooley, P. W., Sujkowski, L. S., Koh, Y. J., Cohen, B. A., Spielman, L. J., Deahl, K. L., Inglis, D. A., and Sandlan, K. P. 1993. Historical and recent migrations of Phytophthora infestans: Chronology, pathways, and implications. Plant Dis. 77:653-661.

5. Fry, W. E., Goodwin, S. B., Matuszak, J. M., Spielman, L. J., Milgroom, M. G., and Drenth, A. 1992. Population genetics and intercontinental migrations of Phytophthora infestans. Annu. Rev. Phytopathol. 30:107-129.

6. Gallegly, M. E., and Galindo, J. 1958. Mating types and oospores of Phytophthora infestans in nature in Mexico. Phytopathology 48:274-277.

7. Gisi, U., and Cohen, Y. 1996. Resistance to phenylamide fungicides: A case study with Phytophthora infestans involving mating type and race structure. Annu. Rev. Phytopathol. 34:549-572.

8. Göts, E. 1991. Untersuchungen zum Auftreten des $A_{2}$ Paarungstyps bei
Phytophthora infestans in Ostdeutschland. Potato Res. 34:233-237.

9. Grinberger, M., Kadish, D., and Cohen, Y. 1989. Occurrence of the $\mathrm{A}_{2}$ mating type and oospores of Phytophthora infestans in potato crops in Israel. Phytoparasitica 17:197-204.

10. Hohl, H. R., and Iselin, K. 1984. Strains of Phytophthora infestans with $\mathrm{A}_{2}$ mating type behaviour. Trans. Br. Mycol. Soc. 83:529-530.

11. Ko, W. H. 1978. Heterothallic Phytophthora: Evidence for hormonal regulation of sexual reproduction. J. Gen. Microbiol. 107:15-18.

12. Ko, W. H. 1980. Hormonal regulation of sexual reproduction in Phytophthora. J. Gen. Microbiol. 116:459-463.

13. Koh, Y. J., Goodwin, S. B., Dyer, A. T., Cohen, B. A., Ogoshi, A., Sato, N., and Fry, W. E. 1994. Migrations and displacements of Phytophthora infestans populations in East Asian countries. Phytopathology 84:922-927.

14. Mosa, A. A., Kato, M., Sato, N., Kobayashi, K., and Ogoshi, A. 1989. Isoenzyme polymorphism and segregation in isolates of Phytophthora infestans from Japan. Ann. Phytopathol. Soc. Jpn. 55:615-670.

15. Niederhauser, J. S. 1991. Phytophthora infestans: The Mexican connection. Pages 25-45 in: Phytophthora. J. A. Lucas, R. C. Shattock, D. S. Shaw, and L. R. Cooke, eds. British Mycological Society, Cambridge University Press, Cambridge.

16. Shaw, D. S., and Shattock, R. C. 1991. Genetics of Phytophthora infestans: The Mendelian approach. Pages 218-230 in: Phytophthora. J. A. Lucas, R. C. Shattock, D. S. Shaw, and L. R. Cooke, eds. British Mycological Society, Cambridge University Press, Cambridge.

17. Smoot, J. J., Gough, F. J., Lamey, H. A., Eichenmuller, J. J., and Gallegly, M. E. 1958. Production and germination of oospores of Phytophthora infestans. Phytopathology 48:165-171.

18. Spielman, L. J., Drenth, A., Davidse, L. C., Sujkowski, L. S., Gu, W., Tooley, P. W., and Fry, W. E. 1991. A second world-wide migration and population displacement of Phytophthora infestans? Plant Pathol. 40: 422-430. 